\title{
Factors associated with high-risk human papillomavirus test utilization and infection: a population-based study of uninsured and underinsured women
}

\author{
Adana A. M. Llanos ${ }^{1,2^{*}}$, Jennifer Tsui ${ }^{2}$, David Rotter ${ }^{2}$, Lindsey Toler $^{3}$ and Antoinette M. Stroup ${ }^{1,2,4}$
}

\begin{abstract}
Background: Current cervical cancer screening guidelines recommend a Pap test every 3 years for women age 2165 years, or for women 30-65 years who want to lengthen the screening interval, a combination of Pap test and high-risk human papilloma virus testing (co-testing) every 5 years. Little population-based data are available on human papilloma virus test utilization and human papilloma virus infection rates. The objective of this study was to examine the patient-level, cervical cancer screening, and area-level factors associated with human papilloma virus testing and infection among a diverse sample of uninsured and underinsured women enrolled in the New Jersey Cancer Early Education and Detection (NJCEED) Program.
\end{abstract}

Methods: We used data for a sample of 50,510 uninsured/underinsured women, age $\geq 29$ years, who screened for cervical cancer through NJCEED between January 1, 2009 and December 31, 2015. Multivariable logistic regression models were used to estimate associations between ever having a human papilloma virus test or a positive test result, and individual- (age, race/ethnicity, birthplace) and area-level covariates (\% below federal poverty level, \% minority, \% uninsured), and number of screening visits.

Results: Only $26.6 \%(13,440)$ of the sample had at least one human papilloma virus test. Among women who underwent testing, 13.3\% (1792) tested positive for human papilloma virus. Most women who were positive for human papilloma virus (99.4\%) had their first test as a co-test. Human papilloma virus test utilization and infection were significantly associated with age, race/ethnicity, birthplace (country), and residential area-level poverty. Rates of human papilloma virus testing and infection also differed significantly across counties in the state of New Jersey.

Conclusions: These findings suggest that despite access to no-cost cervical cancer screening for eligible women, human papilloma virus test utilization was relatively low among diverse, uninsured and underinsured women in New Jersey, and test utilization and infection were associated with individual-level and area-level factors.

Keywords: Cervical cancer screening, HPV, Co-testing, Minority populations, Medically underserved, Uninsured, Disparities

\footnotetext{
* Correspondence: Adana.Llanos@rutgers.edu

'Department of Epidemiology, Rutgers School of Public Health, 683 Hoes

Lane West, Room 211, Piscataway, NJ 08854, USA

2Division of Population Science, Rutgers Cancer Institute of New Jersey, New

Brunswick, NJ, USA

Full list of author information is available at the end of the article
}

(c) The Author(s). 2018 Open Access This article is distributed under the terms of the Creative Commons Attribution 4.0 International License (http://creativecommons.org/licenses/by/4.0/), which permits unrestricted use, distribution, and reproduction in any medium, provided you give appropriate credit to the original author(s) and the source, provide a link to the Creative Commons license, and indicate if changes were made. The Creative Commons Public Domain Dedication waiver (http://creativecommons.org/publicdomain/zero/1.0/) applies to the data made available in this article, unless otherwise stated. 


\section{Background}

Approximately 80 million people are currently infected and 14 million people are newly infected annually with human papillomavirus (HPV) in the United States (US) [1]. Of the over 150 types of HPV identified to date, 13 of them (HPV 16, 18, 31, 33, 35, 39, 45, 51, 52, 56, 58, 59 , and 68) are recognized as human carcinogens and are considered high-risk (HR-HPV) types for cervical cancer [2]. Although all HR-HPVs are associated with increased risk of certain cancers, HPV 16 and 18 are considered the most carcinogenic, as persistent infection of these HR-HPVs are responsible for approximately $70 \%$ of all cervical cancers in women [3].

In 2004, HR-HPV DNA tests were approved by the US Food and Drug Administration (FDA) for use concurrently with cytology (co-testing) as a primary cervical cancer screening test for women age $\geq 30$ years [4]. Then in 2012, published cervical cancer screening guidelines recommended screening for cervical cancer in women aged 21 to 65 years with cytology (Papanicolaou smear) every 3 years or, for women aged 30 to 65 years who want to lengthen the screening interval, screening with a combination of cytology and HPV testing every 5 years [5-7]. Most recently, in 2014, the FDA approved the first HPV DNA test for primary cervical cancer screening in women aged 25 years and older [8].

Little population-based data exist on the utilization of and barriers/facilitators to HPV DNA testing in the US, particularly for minority and medically underserved women with a higher risk of developing cervical cancer. The limited population-based studies on HPV co-test utilization have generally demonstrated low utilization across various population subgroups (approximately $\leq 20 \%$ testing rates) [9-12]; however, more recent data suggest increased HPV co-test utilization by mid-2013 through 2014 in some populations ( $\geq 44 \%$ to as high as $78 \%)[13,14]$. Recent analysis of the National Breast and Cervical Cancer Early Detection Program (NBCCEDP) have suggested a variety of provider-level factors (e.g., provider characteristics, practices, beliefs, etc.) are associated with cervical cancer screening overall and HPV co-test utilization in the NBCCEDP $[9,15-18]$. However, few patient- and area-level characteristics or disparities in HR-HPV DNA test utilization across population subgroups were examined.

Although rates of cervical cancer incidence in New Jersey has been declining dramatically from 1990 (15.0 per 100,000$)$ to $2014(7.5$ per 100,000$)$ at approximately $2.7 \%$ per year $(95 \%$ CI $-2.9,-2.4)$ [14], substantial variation exists in cervical cancer incidence within the state by geographic and population subgroups. For example, Hispanic women in New Jersey and women of all race/ ethnicities residing in at least four counties within the state have cervical cancer incidence rates that are significantly higher than the US average [14]. The objective of this study was to examine the patient-, clinical-, and area-level factors associated with HR-HPV DNA testing and HR-HPV infection among a diverse sample of uninsured and underinsured women enrolled in the New Jersey Cancer Early Education and Detection (NJCEED) Program, which is part of the NBCCEDP.

\section{Methods}

\section{Study sample}

The NJCEED Program is housed within the New Jersey Department of Health (NJDOH) and is funded primarily by the NJDOH and the Centers for Disease Control and Prevention $(\mathrm{CDC})$ to provide screening, diagnostic, and treatment services to eligible individuals for breast, cervical, prostate and colorectal cancers. Eligibility for receipt of NJCEED program services, include low-income (at or below $250 \%$ of the Federal Poverty Level [FPL]) and lack of adequate health insurance (uninsured or underinsured). NJCEED has been providing breast and cervical cancer outreach, education, early detection, screening and follow-up to eligible individuals in New Jersey since 1993 with initial funding through the CDC's Preventive Health and Health Services Block Grant. Statewide coverage, with services being provided in all 21 counties, began on September 1, 1997. Currently, NJCEED program services are provided through 21 contracted lead agencies, with at least one lead agency in each county. The lead agencies work directly with providers within their county to provide services to eligible program participants. Between January 1, 2000 and December 31, 2015, a total of 116,313 unique and eligible women, age 21 to 64 years, received cervical cancer screening services through NJCEED. Among these, 55,827 were enrolled during the study period of interest (January 1, 2009 through December 31, 2015). We further restricted our study sample to women age $\geq 29$ years, who had available data on race/ethnicity and residential zip code (Fig. 1).

\section{Data collection}

A limited data set was extracted and compiled by NJCEED from the Program's Cancer Screening and Tracking System (CaST), which includes data on invasive cancer cases ascertained through annual data linkages with the New Jersey State Cancer Registry (NJSCR). CaST allows the user to track patients through the length of the study and collect information on screening and diagnostic procedures done for breast and cervical cancer (NBCCDEP) and colorectal cancer (CRCCP). Individual-level data for this study were obtained from the Minimum Data Elements (MDEs) of the CaST based on inclusion criteria described above. All identifiers were removed prior to providing the limited data set to study 


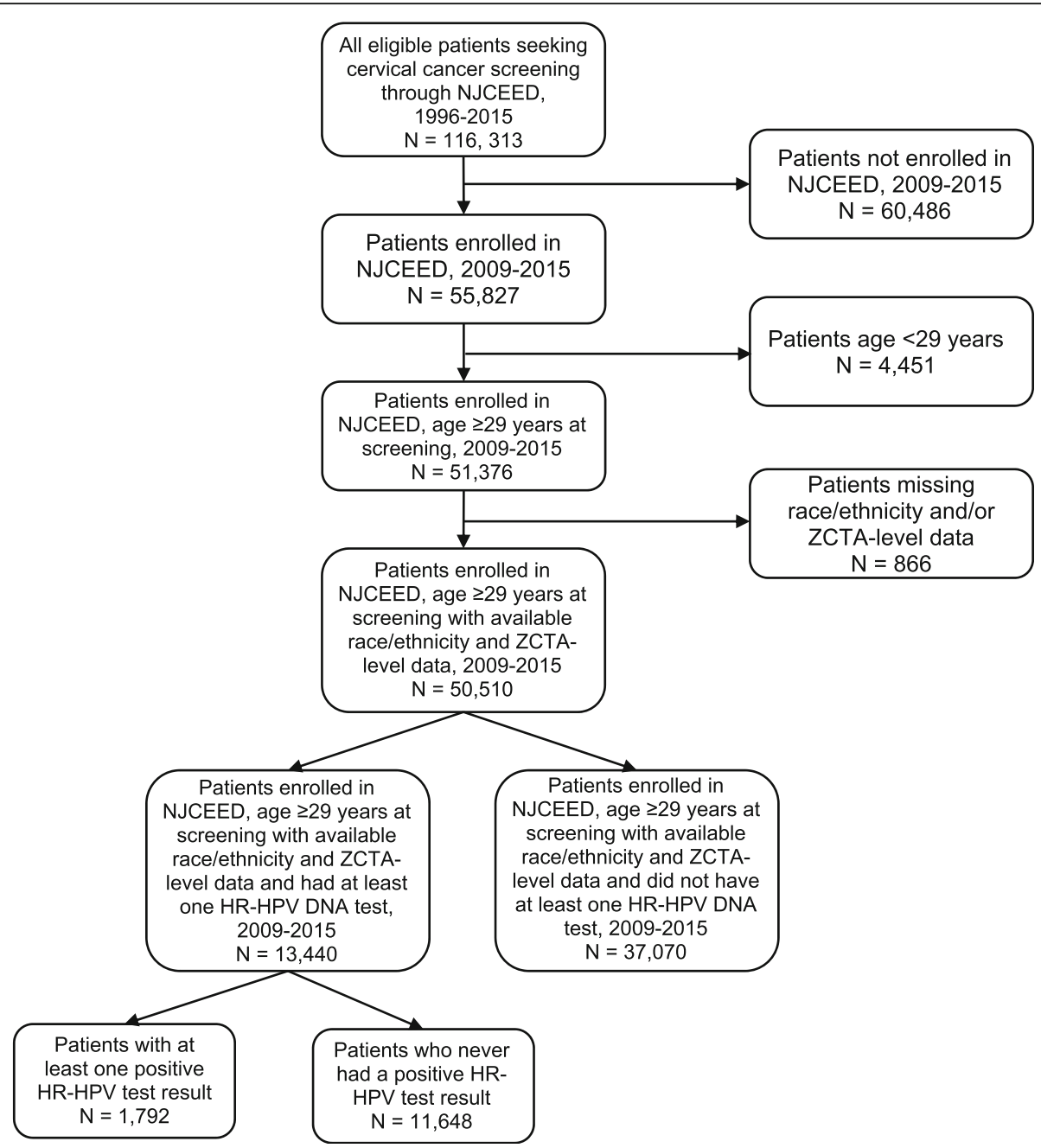

Fig. 1 Flow diagram describing the selection of the analytic cohort

investigators for analysis. Use of the data and all related study activities were approved by the New Jersey Department of Health, Rutgers Biomedical Health Sciences Institutional Review Board, and the Scientific Review Board of Rutgers Cancer Institute of New Jersey.

\section{Patient-level and cervical cancer screening measures}

Age at enrollment was defined as the age at the earliest cervical cancer screening visit during the study period (2009-2015). Race/ethnicity and place of birth were based on patient self-report and stored in CaST. A total of 166 unique countries of birth were reported among participants, which were collapsed into 7 categories: (1) USA, (2) Central and South America, (3) Caribbean, (4) Africa, (5) Asia and the Middle East, (6) Europe, Russia, Australia and Oceania, and (7) Other Countries. In terms of cervical cancer screening variables, number of cervical cancer screening visits was defined as the total number of unique visits to NJCEED providers for any cervical cancer screening procedures at any time during the study period (e.g., gynecologic consultation, Pap test, pelvic exam, HPV test); and number of HR-HPV DNA tests was defined as the total number of unique visits where an HPV test was performed during the study period. HR-HPV DNA test results were only available as positive result or negative result. Specific HR-HPV DNA types (e.g., 16, 18, etc.) for positive results were not available. Age at first Pap test and HPV test were defined as study participant's age at the earliest Pap test or HPV test, respectively, reported during the study period.

\section{Area-level measures}

Residential zip code tabulation area (ZCTA) for each study participant was linked to the 2010-2014 American Community Survey (ACS) 5-year ZCTA-level estimates collected by the US Census Bureau. The following ACS estimates were obtained to derive area-level sociodemographic factors: (1) poverty status in the past 12 months; 
(2) race/ethnicity; (3) health insurance coverage type; and (4) language spoken at home. Proportions of participants falling into quintiles $(1=$ low, $5=$ high) of each of the above sociodemographic factors (based on ZCTA population estimate distributions within the NJCEED population in our study cohort) were estimated. The proportion of minority residents per ZCTA was calculated as the difference of 1 minus the proportion of non-Hispanic White (NHW) residents. Age-adjusted cervical cancer incidence and mortality rates by New Jersey county were obtained from the National Cancer Institute (NCI) State Cancer Profiles [14], which summarizes data from the latest SEER submission (December 2016).

\section{Statistical analysis}

Our primary outcomes of interest are having at least one HR-HPV DNA test and having ever received a positive HR-HPV DNA test. Descriptive statistics were used to summarize the individual sociodemographic and screening characteristics. Chi-square tests were used to compare these variables by HR-HPV DNA test receipt and receipt of a positive HR-HPV DNA test result. We conducted bivariate logistic regression models to examine the relationship between individual-level covariates (age at enrollment, race/ethnicity, country of birth), number of screening visits, and area-level measures with our primary outcomes. Full models were based on significant relationships in the unadjusted models. Tests for multicollinearity were also conducted, with negative results. We ran multivariate models adjusting for year, which was significantly associated with HR-HPV DNA testing rates but not HR-HPV positivity. Upon inclusion of year in the full model, the associations remained mostly consistent. Study participants with missing demographic or zip codes were excluded from analysis. We estimated odds ratios (OR) and 95\% confidence intervals (CI) using robust standard errors and defined significance as $P<$ 0.05 level. County level rates of HR-HPV DNA testing, positive results for HR-HPV DNA test, and invasive cervical cancer incidence and mortality were also examined. Data were analyzed using SAS v9.4 (SAS Institute, Cary, NC) and STATA v14 (StataCorp, College Station, TX).

\section{Results}

Among the 50,510 women included in the analysis, $26.6 \%(13,440)$ had at least one HR-HPV DNA test through NJCEED over the 6-year study period from 2009 to 2015. Among those who ever had a HR-HPV DNA test, $13.3 \%$ (1792) had received a positive test result. Characteristics of the analytic cohort overall, as well as among those ever tested for HR-HPV and among those who ever received a positive HR-HPV test result are shown in Table 1. Overall, a large majority of the study sample was $\geq 40$ years at enrollment in NJCEED (40-49 years, $39.4 \%$; $\geq 50$ years, $44.8 \%$ ), of Hispanic ethnicity (53.4\%), and foreign-born (70.9\%).

In terms of cervical cancer screening, most women had only one screening visit (59.1\%) and had only one Pap test (70.6\%) over 6 years. Additionally, they had their first NJCEED Pap test an older age (40-49 years, $39.4 \%, \geq 50$ years, $44.7 \%$ ). In terms of HR-HPV testing, $73.4 \%$ of the sample were never tested. HR-HPV DNA testing rates among women age $\geq 29$ years increased from $7.4 \%$ in 2009 to $35.4 \%$ in $2015(P<0.0001)$. Compared to women who were never tested for HR-HPV test, those who were tested were more likely to be younger at enrollment into NJCEED, younger at their first Pap and HR-HPV tests, to have more cervical cancer screening visits, to have more Pap tests, and were less likely to be NHW and US-born (all $P$-values $<0.001$ ). Almost all women who had a HR-HPV DNA test through NJCEED had their first test as a co-test with Pap test $(99.8 \%)$ and the first test result was positive among $12.7 \%$ of these women. Like women who had a HR-HPV test, participants who tested positive for HR-HPV were also more likely to be younger at enrollment in NJCEED, younger at their first Pap and HR-HPV DNA tests, to have more cervical cancer screening visits, and to have more Pap tests compared to those who never tested positive for HR-HPV (all $P$-values $<0.001)$. However, unlike the women who were tested, HR-HPV positive women were more likely to be NHW and US-born. Almost all women who had ever received a positive HR-HPV test results (99.4\%) had their first test as a co-test with a Pap test and for $95.5 \%$ of them their first HR-HPV test was positive.

In multivariable-adjusted models, we observed significant associations between age, race/ethnicity, country of birth, cervical cancer screening behaviors, and area-level poverty and having at least one HR-HPV DNA test (Table 2). Women who had their first cervical cancer screening visit at an older age (40-49 years, OR 0.83 , 95\% CI: $0.78-0.88$; $\geq 50$ years, OR 0.63 , 95\% CI: $0.59-$ $0.67)$, were born in Central and South American countries (OR 0.86, 95\% CI: 0.80-0.92) or the Caribbean (OR 0.91, 95\% CI: 0.84-0.98), and resided in a ZCTA with lower proportions of residents below the FPL (Quintiles 1-4), had reduced odds of being tested for HR-HPV. Conversely, racial/ethnic minorities (NHB, OR 1.38, 95\% CI: 1.28-1.49; Asian/Pacific Islander [API], OR 1.23, 95\% CI: 1.03-1.46; Hispanic, OR 1.54, 95\% CI: $1.43-$ 1.66), women born in Asian and the Middle Eastern countries (OR 1.61, 95\% CI: 1.35-1.91) or Europe, Russia, Australia or Oceania (OR 2.18, 95\% CI: 1.94$2.45)$, women who had been screened for cervical cancer more than once (2 times, OR 1.60, 95\% CI: 1.52-1.69; $\geq 3$ times, OR $2.77,95 \%$ CI: $2.61-2.94$ ), and resided in a 
Table 1 Characteristics of women $\geq 29$ years who sought cervical cancer screening services through NJCEED, overall and among those who ever had a high-risk human papilloma virus (HR-HPV) DNA test and those who ever received a positive HR-HPV test result, 2009-2015

\begin{tabular}{|c|c|c|c|c|c|}
\hline \multirow[t]{2}{*}{ Patient-level characteristics } & \multirow{2}{*}{$\begin{array}{l}\text { Total, } N= \\
50,510 \\
\mathrm{n}(\%)\end{array}$} & \multirow{2}{*}{$\begin{array}{l}\text { Ever had a HR-HPV DNA test, } n= \\
13,440^{*} \\
\mathrm{n}(\%)\end{array}$} & \multirow[b]{2}{*}{$p^{a}$} & \multicolumn{2}{|l|}{$\begin{array}{l}\text { Ever received a positive HR-HPVtest result, } \\
n=1792^{* *}\end{array}$} \\
\hline & & & & n (\%) & $P^{b}$ \\
\hline \multicolumn{6}{|l|}{ Sociodemographics } \\
\hline $\begin{array}{l}\text { Age at enrollment into NJCEED } \\
\text { (years) }\end{array}$ & & & $\begin{array}{l}< \\
0.001\end{array}$ & & $<0.001$ \\
\hline 29-39 & $\begin{array}{l}7987 \\
(15.8)\end{array}$ & $2457(18.3)$ & & $532(29.7)$ & \\
\hline $40-49$ & $\begin{array}{l}19,909 \\
(39.4)\end{array}$ & $5663(42.1)$ & & $689(38.4)$ & \\
\hline$\geq 50$ & $\begin{array}{l}22,614 \\
(44.8)\end{array}$ & 5320 (39.6) & & $571(31.9)$ & \\
\hline Race/ethnicity & & & $\begin{array}{l}< \\
0.001\end{array}$ & & $<0.001$ \\
\hline Non-Hispanic White & $\begin{array}{l}12,420 \\
(24.6)\end{array}$ & $2706(20.1)$ & & $443(24.7)$ & \\
\hline Non-Hispanic Black & $\begin{array}{l}7716 \\
(15.3)\end{array}$ & $1993(14.8)$ & & $247(13.8)$ & \\
\hline Asian/Pacific Islander & $3351(6.6)$ & $1060(7.9)$ & & $98(5.5)$ & \\
\hline Hispanic & $\begin{array}{l}27,023 \\
(53.5)\end{array}$ & $7681(57.2)$ & & $1004(56.0)$ & \\
\hline Place of birth & & & $\begin{array}{l}< \\
0.001\end{array}$ & & $<0.001$ \\
\hline USA & $\begin{array}{l}14,695 \\
(29.1)\end{array}$ & $3468(25.8)$ & & $525(29.3)$ & \\
\hline Central and South America & $\begin{array}{l}20,437 \\
(40.5)\end{array}$ & $5575(41.5)$ & & $754(42.1)$ & \\
\hline Caribbean & $\begin{array}{l}7266 \\
(14.4)\end{array}$ & $2007(14.9)$ & & $261(14.6)$ & \\
\hline Africa & $952(1.9)$ & $243(1.8)$ & & $19(1.1)$ & \\
\hline Asia and the Middle East & $3283(6.5)$ & $1075(8.0)$ & & $95(5.3)$ & \\
\hline $\begin{array}{l}\text { Europe, Russia and Australia and } \\
\text { Oceania }\end{array}$ & $1549(3.1)$ & $546(4.1)$ & & $61(3.4)$ & \\
\hline Other countries $^{c}$ & $2328(4.6)$ & $526(3.9)$ & & $77(4.3)$ & \\
\hline \multicolumn{6}{|l|}{ Cervical cancer screening characteristics } \\
\hline Number of cervical screening visits & & & $\begin{array}{l}< \\
0.001\end{array}$ & & $<0.001$ \\
\hline 1 & $\begin{array}{l}29,872 \\
(59.1)\end{array}$ & $7399(55.1)$ & & $842(47.0)$ & \\
\hline 2 & $\begin{array}{l}8760 \\
(17.3)\end{array}$ & $2488(18.5)$ & & $356(19.9)$ & \\
\hline$\geq 3$ & $\begin{array}{l}11,878 \\
(23.5)\end{array}$ & $3553(26.4)$ & & $594(33.1)$ & \\
\hline Number of Pap tests & & & $\begin{array}{l}< \\
0.001\end{array}$ & & \\
\hline 0 & $1571(3.1)$ & $10(0.1)$ & & $4(0.2)$ & \\
\hline 1 & $\begin{array}{l}35,670 \\
(70.6)\end{array}$ & $8488(63.2)$ & & $967(54.0)$ & \\
\hline 2 & $\begin{array}{l}8347 \\
(16.5)\end{array}$ & $2717(20.2)$ & & $379(21.1)$ & \\
\hline
\end{tabular}


Table 1 Characteristics of women $\geq 29$ years who sought cervical cancer screening services through NJCEED, overall and among those who ever had a high-risk human papilloma virus (HR-HPV) DNA test and those who ever received a positive HR-HPV test result, 2009-2015 (Continued)

\begin{tabular}{|c|c|c|c|c|c|}
\hline \multirow[t]{2}{*}{ Patient-level characteristics } & \multirow{2}{*}{$\begin{array}{l}\text { Total, } N= \\
50,510 \\
\mathrm{n}(\%)\end{array}$} & \multirow{2}{*}{$\begin{array}{l}\text { Ever had a HR-HPV DNA test, } n= \\
13,440^{*} \\
\text { n (\%) }\end{array}$} & \multirow[b]{2}{*}{$p^{a}$} & \multirow{2}{*}{$\begin{array}{l}\text { Ever received a positive HR-HPVtest result, } \\
n=1792^{* *} \\
\mathrm{n}(\%)\end{array}$} & \multirow[b]{2}{*}{$p^{b}$} \\
\hline & & & & & \\
\hline$\geq 3$ & $4922(9.7)$ & $2230(16.6)$ & & $442(24.7)$ & \\
\hline Age at first Pap test (years) & & & $\begin{array}{l}< \\
0.001\end{array}$ & & \\
\hline 29-39 & $\begin{array}{l}7778 \\
(15.9)\end{array}$ & $2450(18.2)$ & & $529(29.6)$ & \\
\hline $40-49$ & $\begin{array}{l}19,291 \\
(39.4)\end{array}$ & $5658(42.1)$ & & $688(38.5)$ & \\
\hline$\geq 50$ & $\begin{array}{l}21,870 \\
(44.7)\end{array}$ & $5322(39.6)$ & & $571(31.9)$ & \\
\hline Number of HPV tests & & & $\begin{array}{l}< \\
0.001\end{array}$ & & $<0.001$ \\
\hline 0 & $\begin{array}{l}37,070 \\
(73.4)\end{array}$ & $0(0.0)$ & & $0(0.0)$ & \\
\hline 1 & $\begin{array}{l}11,810 \\
(23.4)\end{array}$ & $11,810(87.9)$ & & 1391 (77.6) & \\
\hline 2 & $1386(2.7)$ & $1386(10.3)$ & & $306(17.1)$ & \\
\hline$\geq 3$ & $244(0.5)$ & $244(1.8)$ & & $95(5.3)$ & \\
\hline Age at first HPV test (years) & & & - & & $<0.001$ \\
\hline 29-39 & & $2307(17.2)$ & & $514(28.7)$ & \\
\hline $40-49$ & & $5461(40.6)$ & & $673(37.6)$ & \\
\hline$\geq 50$ & & $5672(42.2)$ & & $605(33.8)$ & \\
\hline
\end{tabular}

Abbreviations: FPL federal poverty level, HR-HPV high-risk human papillomavirus, NJCEED New Jersey Cancer Early Education and Detection, USA United States of America, ZCTA ZIP Code Tabulation Area. Bolded values represent statistically significant associations $(P<0.05)$

* Of the 50,510 NJCEED patients $\geq 29$ years included in the analytic sample, 13,440 (26.6\%) had at least one HR-HPV DNA test

**Of the 13,440 NJCEED patients $\geq 29$ years included in the analytic sample, $1792(13.3 \%)$ had at least one positive HR-HPV DNA test result

${ }^{a} P$-values were calculated using chi-square tests comparing women who ever had a HR-HPV DNA test to those who did not

${ }^{\mathrm{b}} P$-values were calculated using chi-square tests comparing women who ever had a positive HR-HPV DNA test result to those who did not

Includes women born in Canada as well as those reporting other or unspecified countries outside the USA

ZCTA with a high proportion of residents living below the FPL (Quintile 5, OR 1.50, 95\% CI: 1.41-1.61) had increased odds of being tested for HR-HPV.

In multivariable-adjusted models, we also observed significant associations between age, race/ethnicity, country of birth, cervical cancer screening patterns, and area-level poverty and the odds of testing positive for HR-HPV (Table 3). Women who enrolled in NJCEED at an older age ( $40-49$ years, OR $0.46,95 \% \mathrm{CI}: 0.40-0.52$; $\geq 50$ years, OR 0.40, 95\% CI: 0.35-0.46), were NHB (OR 0.75, 95\% CI: 0.62-0.90) or Hispanic (OR 0.66, 0.55-0.79), and born in Africa (OR 0.54, 95\% CI: 0.33-0.89), Asia or the Middle East (OR 0.53, 95\% CI: 0.33-0.86), or Europe, Russia, Australia or Oceania (OR 0.63, 95\% CI: 0.47-0.84) had decreased odds of testing positive for HR-HPV. Women who were more frequently screened for cervical cancer $(2$ times, OR 1.31, 95\% CI: 1.15-1.49; $\geq 3$ times, OR 1.86, 95\% CI: 1.64-2.11) and resided in a ZCTA with relatively low proportions of residents below the FPL (Quintiles 12) had increased odds of testing positive for HR-HPV.
In our analysis of HR-HPV DNA testing and HR-HPV infection by New Jersey county of residence, we found that the rates of HR-HPV DNA testing among residents of eight counties were significantly higher than the $26.6 \%$ overall rate of testing in the study sample (Bergen, 69.4\%; Mercer, 64.2\%; Passaic, 60.0\%; Morris, 53.0\%; Hunterdon, 41.8\%; Cumberland, 40.2\%; Essex, 38.8\%; and Middlesex, 34.2\%; all $P$-values < 0.0001 ) (Fig. 2). In terms of HR-HPV infection, five of the counties with testing rates higher than the sample average had lower than the $13.3 \%$ overall average for HR-HPV infection (Bergen, 9.2\%, $P<0.0001$; Mercer, 11.7\%, $P=0.002$; Morris, 6.2\%, $\mathrm{P}<0.0001$; Cumberland, $12.7 \%, P=0.007$, and Essex, 8.4\%, $\mathrm{P}<0.0001$ ), while several other counties had HR-HPV infection rates that were 2- to 3-fold higher than the sample average (Atlantic, 26.3\%; Somerset, 26.7\%; and Monmouth, 44.2\%; all P-values <0.0001). Figure 3 shows HR-HPV testing and infection rates (per 1000 NJCEED participants) and age-adjusted cervical cancer incidence and mortality rates from 2010 to 2014 
Table 2 Logistic regression analysis of factors associated with having at least one HR-HPV DNA test among women who sought cervical care through NJCEED, 2009-2015

\begin{tabular}{|c|c|c|c|}
\hline & $\begin{array}{l}\text { Proportion that ever had a HR-HPV DNA test } \\
\text { (\%) }\end{array}$ & $\begin{array}{l}\text { Unadjusted OR (95\% } \\
\text { Cl) }\end{array}$ & $\begin{array}{l}\text { Multivariable-adjusted OR (95\% } \\
\text { Cl) }\end{array}$ \\
\hline \multicolumn{4}{|l|}{ Age at enrollment into NJCEED (years) } \\
\hline 29-39 & 30.8 & 1.00 (ref) & 1.00 (ref) \\
\hline $40-49$ & 28.5 & $0.89(0.84-0.95)$ & $0.83(0.78-0.88)$ \\
\hline$\geq 50$ & 23.5 & $0.69(0.65-0.73)$ & $0.63(0.59-0.67)$ \\
\hline \multicolumn{4}{|l|}{ Race/ethnicity } \\
\hline Non-Hispanic White & 21.8 & 1.00 (ref) & 1.00 (ref) \\
\hline Non-Hispanic Black & 25.8 & $1.25(1.17-1.33)$ & $1.38(1.28-1.49)$ \\
\hline Asian/Pacific Islander & 31.6 & $1.66(1.52-1.80)$ & $1.23(1.03-1.46)$ \\
\hline Hispanic & 28.4 & $1.42(1.35-1.50)$ & $1.54(1.43-1.66)$ \\
\hline \multicolumn{4}{|l|}{ Place of birth } \\
\hline USA & 23.6 & 1.00 (ref) & 1.00 (ref) \\
\hline Central and South America & 27.3 & $1.21(1.15-1.27)$ & $0.86(0.80-0.92)$ \\
\hline Caribbean & 27.6 & $1.23(1.16-1.31)$ & $0.91(0.84-0.98)$ \\
\hline Africa & 25.5 & $1.11(0.95-1.31)$ & $1.00(0.85-1.17)$ \\
\hline Asia and the Middle East & 32.7 & $1.57(1.45-1.71)$ & $1.61(1.35-1.91)$ \\
\hline $\begin{array}{l}\text { Europe, Russia and Australia and } \\
\text { Oceania }\end{array}$ & 35.3 & $1.76(1.58-1.97)$ & $2.18(1.94-2.45)$ \\
\hline Other countries ${ }^{a}$ & 22.7 & $0.95(0.85-1.05)$ & $0.95(0.85-1.06)$ \\
\hline \multicolumn{4}{|l|}{ Number of cervical screening visits } \\
\hline 1 & 22.7 & 1.00 (ref) & 1.00 (ref) \\
\hline 2 & 31.5 & $1.56(1.48-1.64)$ & $1.60(1.52-1.69)$ \\
\hline$\geq 3$ & 43.1 & $2.58(2.43-2.73)$ & $2.77(2.61-2.94)$ \\
\hline \multicolumn{4}{|c|}{ Proportion of residents in ZCTA who are below the FPL } \\
\hline Quintile $1(0.0-6.9 \%)$ & 27.2 & 1.00 (ref) & 1.00 (ref) \\
\hline Quintile 2 (7.0-10.8\%) & 23.3 & $0.79(0.74-0.85)$ & $0.79(0.74-0.85)$ \\
\hline Quintile 3 (10.9-18.5\%) & 23.7 & $0.81(0.76-0.87)$ & $0.81(0.76-0.87)$ \\
\hline Quintile 4 (18.7-23.7\%) & 21.9 & $0.73(0.69-0.78)$ & $0.77(0.72-0.82)$ \\
\hline Quintile 5 (24.4-100.0\%) & 35.9 & $1.47(1.38-1.56)$ & $1.50(1.41-1.61)$ \\
\hline \multicolumn{4}{|c|}{ Proportion of minority residents in ZCTA } \\
\hline Quintile $1(0.0-26.6 \%)$ & 20.0 & 1.00 (ref) & \\
\hline Quintile 2 (26.7-49.0\%) & 24.2 & $1.27(1.19-1.36)$ & \\
\hline Quintile 3 (50.4-76.4\%) & 34.0 & $2.06(1.93-2.19)$ & \\
\hline Quintile 4 (76.5-87.2\%) & 21.4 & $1.09(1.01-1.16)$ & \\
\hline Quintile 5 (87.8-98.8\%) & 32.9 & $1.96(1.84-2.09)$ & \\
\hline \multicolumn{4}{|c|}{ Proportion of uninsured residents in ZCTA } \\
\hline Quintile $1(0.0-13.0 \%)$ & 24.4 & 1.00 (ref) & \\
\hline Quintile 2 (13.1-20.3\%) & 22.8 & $0.91(0.86-0.98)$ & \\
\hline Quintile 3 (20.4-28.8\%) & 29.4 & $1.29(1.21-1.37)$ & \\
\hline Quintile 4 (29.2-37.9\%) & 26.3 & $1.11(1.04-1.18)$ & \\
\hline Quintile 5 (38.1-100.0\%) & 30.3 & $1.35(1.27-1.43)$ & \\
\hline \multicolumn{4}{|c|}{ Proportion of residents in ZCTA who don't speak English very well } \\
\hline Quintile $1(0.0-5.7 \%)$ & 19.0 & 1.00 (ref) & \\
\hline Quintile 2 (5.8-11.3\%) & 24.4 & $1.38(1.29-1.47)$ & \\
\hline
\end{tabular}


Table 2 Logistic regression analysis of factors associated with having at least one HR-HPV DNA test among women who sought cervical care through NJCEED, 2009-2015 (Continued)

\begin{tabular}{|c|c|c|c|}
\hline & $\begin{array}{l}\text { Proportion that ever had a HR-HPV DNA test } \\
\text { (\%) }\end{array}$ & $\begin{array}{l}\text { Unadjusted OR (95\% } \\
\text { Cl) }\end{array}$ & $\begin{array}{l}\text { Multivariable-adjusted OR (95\% } \\
\text { Cl) }\end{array}$ \\
\hline Quintile 3 (11.4-19.1\%) & 29.6 & $1.79(1.68-1.91)$ & \\
\hline Quintile 4 (19.2-34.3\%) & 35.7 & $2.36(2.21-2.52)$ & \\
\hline Quintile 5 (34.6-51.6\%) & 24.8 & $1.41(1.31-1.50)$ & \\
\hline
\end{tabular}

Multivariable-adjusted model was adjusted for all variables listed. Area-level measures are based on the distributions of the NJCEED study sample. We also tested the effect of including year (which was significantly associated with HR-HPV DNA testing rates, and the observed associations remained consistent, except the association between age and HR-HPV DNA testing, which showed that when year is included in the model, there was a stronger inverse association for the 4049 years age group (OR $0.46,95 \% \mathrm{Cl}: 0.40-0.52)$. Bolded values represent statistically significant associations $(P<0.05)$

(per 100,000 New Jersey residents, based on NCI State Cancer Profiles data [14]). This figure shows that 4 of the $5 \mathrm{New}$ Jersey counties with the highest rates of HPV testing (398.04-694.02 per 1000) also have the highest rates of HPV positivity (50.57-100.96 per 1000) (Bergen, Passaic, Hunterdon, and Mercer). Some counties with low to moderate rates of HPV testing among NJCEED participants are among the counties (Atlantic, Essex, and Hudson) with highest rates of cervical cancer incidence $(9.10-11.40$ per 100,000$)$ and mortality $(2.20-3.80$ per 100,000).

\section{Discussion}

In this study, we estimated utilization rates of HR-HPV DNA testing and examined the factors associated with HR-HPV DNA testing and HR-HPV infection among a diverse sample of medically underserved women in New Jersey seeking cervical cancer screening services through NJCEED. We observed relatively low rates of HR-HPV test utilization (26.6\%) among this sample of eligible women. We also observed wide variation in HR-HPV DNA test utilization and HR-HPV infection by individual-level (age, race/ethnicity, birthplace, cervical cancer screening patterns) and area-level characteristics (poverty), as well as by county of residence. Of note, while non-Hispanic Black and Hispanic patients had higher odds of HR-HPV DNA test use, they were significantly less likely to be HR-HPV-infected compared to NHWs.

Few studies have examined the rates of HR-HPV DNA testing in cervical cancer prevention [9-12], but they yielded similarly low utilization as we report here. Cuzick et al. [11], in the first US study to report on population-based utilization of HPV DNA testing (specifically co-testing) in cervical cancer screening, showed HPV test utilization was $11.9 \%$ among women $15-$ 65 years from 2007 to 2012 in New Mexico. Similar to our findings of an increase in the rates of HPV testing across the study period, the study by Cuzick and colleagues also showed an increase in HPV co-test utilization among women 30-65 years from 5.2\% in 2007 to $19.1 \%$ in 2012 [11]. Another study [10], which estimated HPV testing in cervical cancer using laboratory and administrative data from Johns Hopkins Hospital found that between February 2004 and December 2007, HPV co-test utilization among women $\geq 30$ years was $7.8 \%$ in Baltimore, Maryland. This study also showed an increase in test utilization from $2.2 \%$ in 2005 to $15 \%$ in 2006, which plateaued around 13\% in 2007 [10]. A study examining data from 4 health systems (Group Health Cooperative [Washington], Kaiser Permanente Northwest [Oregon/Washington], Kaiser Permanente Hawaii, and Reliant Medical Group [Massachusetts]) between 1998 and 2007 [12], found that HPV co-testing became the guideline for these health systems in 2005 and that the rate of HPV co-testing was 130 per 1000 person-years in 2007.

Similar to our current study, another study [9] examining HPV DNA test utilization (although not focusing on co-testing explicitly) between July 2001 and June 2006 among Florida Medicaid enrollees found that only $2.9 \%$ of Medicaid beneficiaries received a HPV DNA test during the study period. This study showed that HPV DNA test use increased over the study period from $0.6 \%$ in 2001 to $9 \%$ in 2006 [9]. Our study showed that $26.6 \%$ of women who sought cervical cancer screening through NJCEED from 2009 to 2015 were tested at least once for HR-HPV and among them, $13.3 \%$ tested positive for HR-HPV infection. Almost all of the women who tested positive in this study (99.4\%) had their first HR-HPV DNA test as a co-test with Pap test. Findings from our study as well as these previous studies [9-12] highlight the low utilization of HPV DNA testing among uninsured/underinsured, vulnerable populations in several geographic regions in the US, which may be due to lack of providers' recommendations for HPV testing for various reasons (e.g., high costs/ limited funding, providers' practices and beliefs, etc.). While emerging data, based on hospital pathology records [13] and healthcare claims data [14] suggest increasing uptake of HPV co-testing, little data exist on utilization among hard to reach, uninsured and underinsured populations. Additional studies are needed to understand the barriers to utilization of HR-HPV DNA testing, particularly among high risk populations, and to develop strategies to increase the utilization rates of this important cervical cancer screening test. 
Table 3 Logistic regression analysis of factors associated with ever receiving a positive HR-HPV DNA test result among women who had at least one HR-HPV DNA test through NJCEED, 2009-2015

\begin{tabular}{|c|c|c|c|}
\hline & $\begin{array}{l}\text { Proportion that ever received a positive HR-HPV test } \\
\text { result (\%) }\end{array}$ & $\begin{array}{l}\text { Unadjusted OR } \\
(95 \% \mathrm{Cl})\end{array}$ & $\begin{array}{l}\text { Multivariable-adjusted OR } \\
(95 \% \mathrm{Cl})\end{array}$ \\
\hline \multicolumn{4}{|l|}{ Age at enrollment into NJCEED (years) } \\
\hline $29-39$ & 21.7 & 1.00 (ref) & 1.00 (ref) \\
\hline $40-49$ & 12.2 & $0.50(0.44-0.57)$ & $0.46(0.40-0.52)$ \\
\hline$\geq 50$ & 10.7 & $0.44(0.38-0.50)$ & $0.40(0.35-0.46)$ \\
\hline \multicolumn{4}{|l|}{ Race/ethnicity } \\
\hline Non-Hispanic White & 16.4 & 1.00 (ref) & 1.00 (ref) \\
\hline Non-Hispanic Black & 12.4 & $0.72(0.61-0.85)$ & $0.75(0.62-0.90)$ \\
\hline Asian/Pacific Islander & 9.2 & $0.52(0.41-0.66)$ & $0.94(0.58-1.51)$ \\
\hline Hispanic & 13.1 & $0.77(0.68-0.87)$ & $0.66(0.55-0.79)$ \\
\hline \multicolumn{4}{|l|}{ Country/region of birth } \\
\hline USA & 15.1 & 1.00 (ref) & 1.00 (ref) \\
\hline Central and South America & 13.5 & $0.88(0.78-0.99)$ & $0.96(0.81-1.15)$ \\
\hline Caribbean & 13.0 & $0.84(0.71-0.98)$ & $1.07(0.88-1.29)$ \\
\hline Africa & 7.8 & $0.48(0.29-0.77)$ & $0.54(0.33-0.89)$ \\
\hline Asia and the Middle East & 8.8 & $0.54(0.43-0.68)$ & $0.53(0.33-0.86)$ \\
\hline Europe, Russia and Australia and Oceania & 11.2 & $0.71(0.53-0.93)$ & $0.63(0.47-0.84)$ \\
\hline Other countries ${ }^{a}$ & 14.6 & $0.96(0.74-1.25)$ & $1.01(0.77-1.32)$ \\
\hline \multicolumn{4}{|l|}{ Number of cervical screening visits } \\
\hline 1 & 11.5 & 1.00 (ref) & 1.00 (ref) \\
\hline 2 & 14.0 & $1.26(1.11-1.43)$ & $1.31(1.15-1.49)$ \\
\hline$\geq 3$ & 18.5 & $1.75(1.55-1.98)$ & $1.86(1.64-2.11)$ \\
\hline \multicolumn{4}{|c|}{ Proportion of residents in ZCTA who are below the FPL } \\
\hline Quintile $1(0.0-6.9 \%)$ & 11.7 & 1.00 (ref) & 1.00 (ref) \\
\hline Quintile 2 (7.0-10.8\%) & 14.6 & $1.29(1.10-1.52)$ & $1.23(1.04-1.45)$ \\
\hline Quintile 3 (10.9-18.5\%) & 16.1 & $1.45(1.23-1.70)$ & $1.46(1.24-1.72)$ \\
\hline Quintile 4 (18.7-23.7\%) & 12.6 & $1.09(0.92-1.30)$ & $1.15(0.96-1.38)$ \\
\hline Quintile 5 (24.4-100.0\%) & 12.5 & $1.08(0.93-1.26)$ & $1.12(0.95-1.32)$ \\
\hline \multicolumn{4}{|l|}{ Proportion of minority residents in ZCTA } \\
\hline Quintile $1(0.0-26.6 \%)$ & 15.2 & 1.00 (ref) & \\
\hline Quintile 2 (26.7-49.0\%) & 16.2 & $1.07(0.91-1.26)$ & \\
\hline Quintile 3 (50.4-76.4\%) & 11.0 & $0.69(0.59-0.81)$ & \\
\hline Quintile 4 (76.5-87.2\%) & 14.6 & $0.95(0.80-1.13)$ & \\
\hline Quintile 5 (87.8-98.8\%) & 11.8 & $0.75(0.64-0.87)$ & \\
\hline \multicolumn{4}{|l|}{ Proportion of uninsured residents in ZCTA } \\
\hline Quintile $1(0.0-13.0 \%)$ & 13.0 & 1.00 (ref) & \\
\hline Quintile 2 (13.1-20.3\%) & 15.7 & $1.24(1.05-1.46)$ & \\
\hline Quintile 3 (20.4-28.8\%) & 12.8 & $0.97(0.83-1.14)$ & \\
\hline Quintile 4 (29.2-37.9\%) & 13.2 & $1.01(0.86-1.19)$ & \\
\hline Quintile 5 (38.1-100.0\%) & 12.5 & $0.95(0.81-1.12)$ & \\
\hline \multicolumn{4}{|c|}{ Proportion of residents in ZCTA who don't speak English very well } \\
\hline Quintile $1(0.0-5.7 \%)$ & 16.5 & 1.00 (ref) & \\
\hline Quintile 2 (5.8-11.3\%) & 14.5 & $0.86(0.73-1.02)$ & \\
\hline Quintile 3 (11.4-19.1\%) & 11.5 & $0.66(0.56-0.77)$ & \\
\hline
\end{tabular}


Table 3 Logistic regression analysis of factors associated with ever receiving a positive HR-HPV DNA test result among women who had at least one HR-HPV DNA test through NJCEED, 2009-2015 (Continued)

\begin{tabular}{llll}
\hline & $\begin{array}{l}\text { Proportion that ever received a positive HR-HPV test } \\
\text { result (\%) }\end{array}$ & $\begin{array}{l}\text { Unadjusted OR } \\
(95 \% \mathrm{Cl})\end{array}$ & $\begin{array}{l}\text { Multivariable-adjusted OR } \\
(95 \% \mathrm{Cl})\end{array}$ \\
\hline Quintile 4 (19.2-34.3\%) & 12.3 & $\mathbf{0 . 7 1}(\mathbf{0 . 6 1 - 0 . 8 3 )}$ & \\
Quintile 5 (34.6-51.6\%) & 13.5 & $\mathbf{0 . 7 9}(\mathbf{0 . 6 7 - 0 . 9 3 )}$ & \\
\hline
\end{tabular}

Multivariable-adjusted model was adjusted for all variables listed. Area-level measures are based on the distributions of the NJCEED study sample. We also tested the effect of including year (which was significantly associated with HR-HPV DNA testing rates but not HR-HPV infection), and the observed associations remained consistent. Bolded values represent statistically significant associations $(P<0.05)$

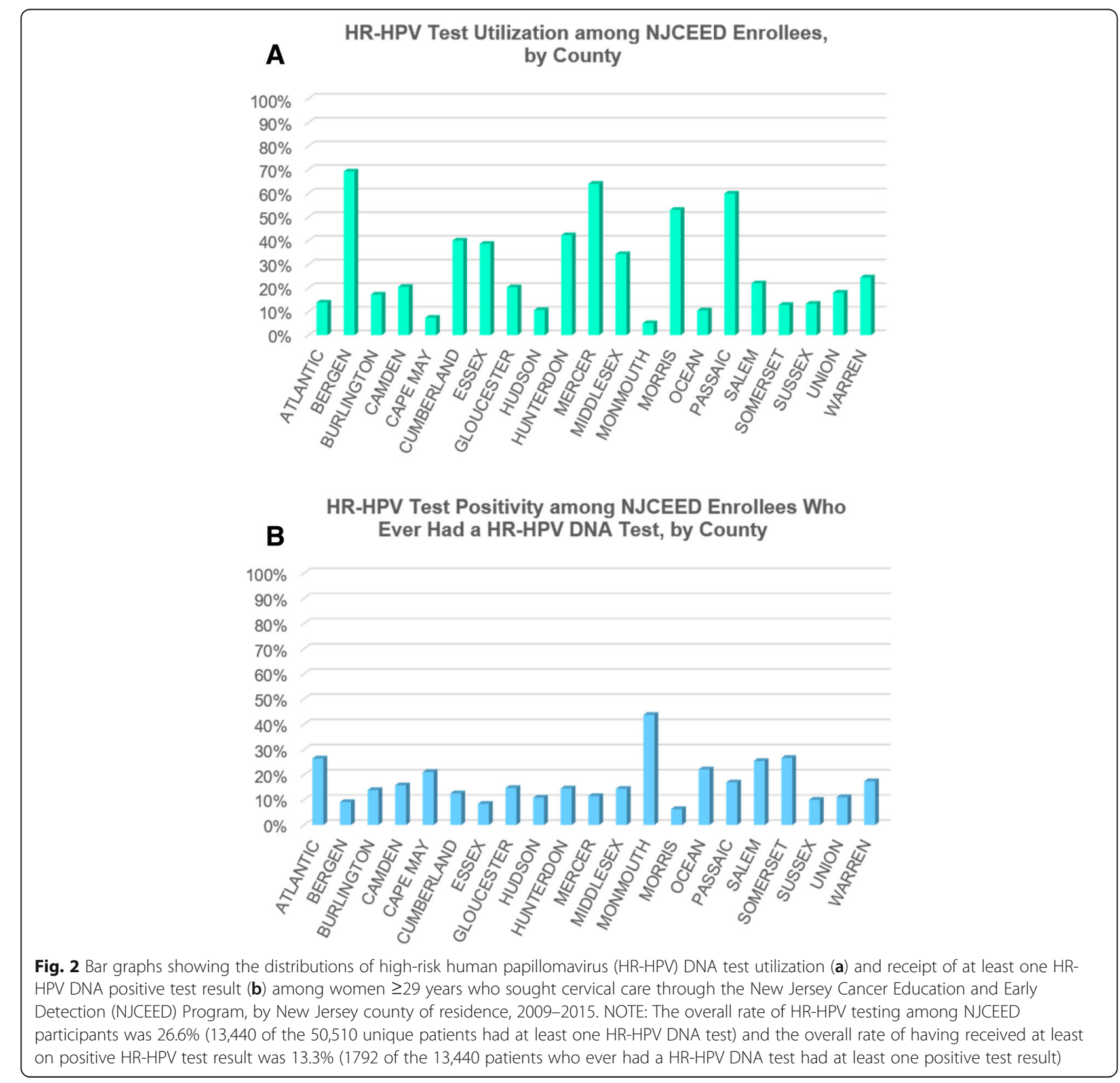


HR-HPV testing rates among NJCEED participants by county

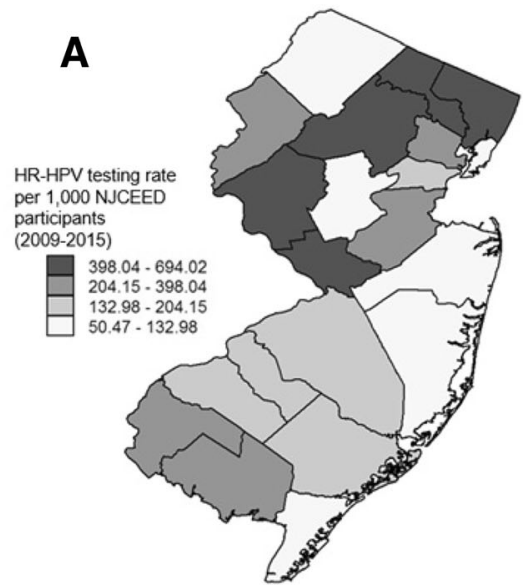

Age-adjusted cervical cancer incidence rates by county

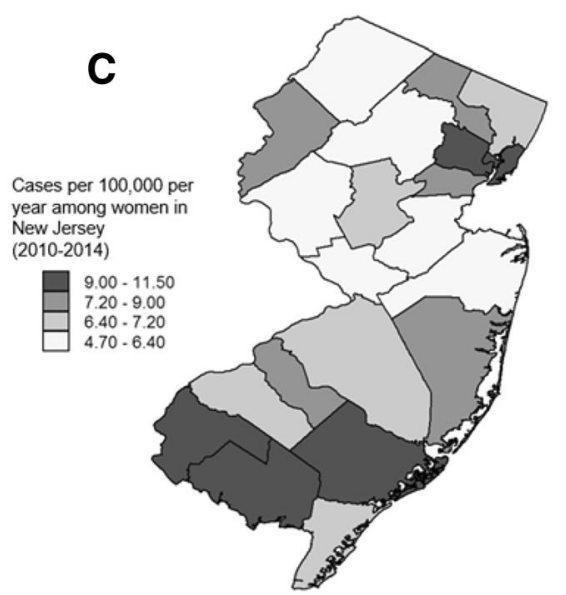

HR-HPV infection rates among NJCEED participants who had at least one HR-HPV DNA test by county

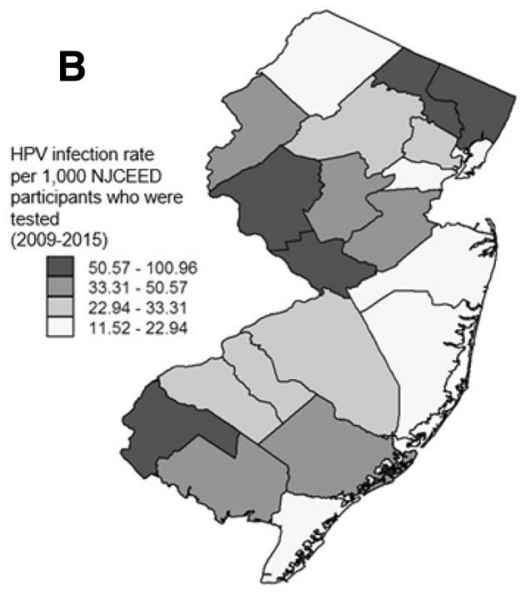

Age-adjusted cervical cancer mortality rates by county

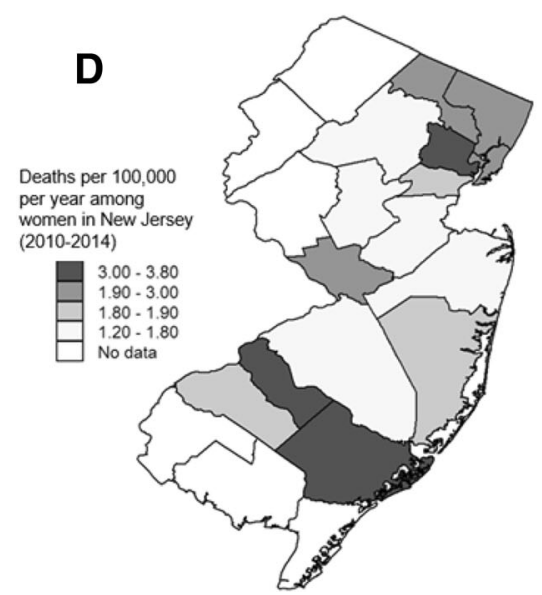

Fig. 3 Maps showing high-risk human papillomavirus (HR-HPV) DNA testing rates among NJCEED participants during the study period (20092015), by county (a); HR-HPV infection among NJCEED participants who received at least one HR-HPV DNA test during the study period (20092015), by county (b); Age-adjusted cervical cancer incidence rates per 100,000 per year among all women in New Jersey (2010-2014), by county (c); and Age-adjusted cervical cancer mortality rates per 100,000 per year among all women in New Jersey (2010-2014), by county (d). NOTE: The rates of HR-HPV testing and infection are only among NJCEED participants (Fig. $3 a$ and b), whereas the incidence and mortality rates of invasive cervical cancer are among all women in New Jersey (Fig. 3c and d). The maps depicted here are our own and were created using data from among the 50,510 NJCEED-enrolled women included in the analysis (Fig. 3a and b) and New Jersey State cervical cancer incidence and mortality data retrieved from www.statecancerprofiles.cancer.gov (Fig. 3c and d)

We observed wide variation in HR-HPV DNA test utilization and HR-HPV infection by individual-level and area-level characteristics. After controlling for covariates, NHBs, APIs, and Hispanics (compared to NHWs) and residents of ZCTAs with larger proportions of residents living below FPL (quintile 5 vs. quintile 1) had higher odds of ever being tested for HR-HPV. The higher odds of HR-HPV DNA testing among NHBs, Hispanics, and women living in high poverty areas were particularly interesting given that there are striking disparities in the cervical cancer burden in these groups, despite widespread reductions in incidence and mortality. Minority, uninsured and low socioeconomic status (SES) women tend to be screened less often and this lower screening tends to result in increased cervical cancer morbidity and mortality [19-21]. These findings suggests that NJCEED is generally reaching the appropriate target population in these areas (minority and low SES women) for cervical cancer screening, which will ultimately have an impact on cervical cancer burden in the state of New Jersey and indicate that although the women seeking screening through NJCEED are medically underserved, they may very well be more health-seeking than expected (in terms of cervical cancer screening). Prior studies have shown reduced barriers to accessing care (e.g., transportation, walkability, availability of clinics) and in some cases increased health care 
utilization among individuals residing in the most inner city, socioeconomically deprived areas compared to those residing in less socioeconomically deprived areas outside of the immediate inner city [22-26]. Furthermore, geographic variations in testing across the state and lower screening rates in specific NJCEED Program areas, particularly more rural areas with low SES women, warrants a focus on targeted strategies for women living in these areas who may face different barriers than urban, minority women.

We also found that the odds of HPV testing decreases as age increases, a finding which has been reported by other investigators [10]. Additionally, we found that women born in Central and South America and the Caribbean had lower odds of ever having a HPV DNA test compared to US-born women. While no other study has reported this association, lower Pap test utilization has been previously reported among foreign-born women [27-31]. Given the projected changes to the composition of the US population, in which the population of native and foreign-born minorities is expected to grow substantially [32], it is essential that cervical cancer prevention and control initiatives begin to focus on developing effective strategies for increasing cervical cancer screening, particularly among foreign-born women, as they tend to experience greater barriers to cancer screening [27-30] and may be at increased risk of cervical cancer (compared to US-born women) due to the prevalence of HPV infection and other risk factors in their native countries [33, 34].

We found that among women who ever had a HPV DNA test, $13.3 \%$ of them had at least one positive test, indicating infection with one or more HR-HPV types. Our finding that NHB and Hispanics had lower odds of ever having a positive HPV test, although having higher odds of ever having a HPV DNA test, was unexpected, given existing data that show higher rates of HPV infection among low SES, minority women, which has been linked to their disproportionate burden of cervical cancer [19, $21,35-38]$. It is unclear whether women reached by NJCEED are inherently more activated individuals and therefore may have other characteristics that relate to decreased prevalence of HR-HPV infection. Of particular importance would be further examination of the risk factors associated with HR-HPV type-specific infection among women screened for cervical cancer through NJCEED, which would have implications related to the benefit of HPV vaccination for cervical cancer prevention among some subgroups. Furthermore, such data will also contribute to the development of targeted interventions to promote improved cervical cancer control among minority and medically underserved women.

The observed variation in HR-HPV DNA test utilization by New Jersey county of residence identified several counties with rates higher than the average of the study sample, which indicates that NJCEED providers covering these areas are doing relatively well at providing guideline cervical cancer screening in medically underserved populations in the state. However, we also identified several counties that had HPV screening rates that were quite low. While we did not examine provider characteristics in the current study, we hypothesize that they are important to understanding variation in cervical cancer screening and HPV DNA testing across counties and by NJCEED providers. Prior studies have shown that variation exists in providers' adherence to screening guidelines and specifically in recommendations for HPV testing [16, 39-42].

The strengths of this study include its large sample size of diverse, uninsured and underinsured women who sought cervical cancer screening services through NJCEED during the study period. Availability of cervical cancer screening history through large administrative data for several years was also a strength. An additional strength is that our findings will contribute to the dearth of population-based data related to HR-HPV test utilization and HR-HPV infection in a diverse sample of women. There were also some limitations of this study that should be considered in the interpretation of our findings. First, the use of administrative data from the NJCEED Program limited the availability of additional covariates of interest, including specific individual-level SES measures and more detailed information on sexual behaviors and other risk factors for HR-HPV infection and HPV vaccination status among study participants. Additionally, we cannot confirm that women included in this study did not seek cervical cancer screening outside of NJCEED during the study period. We also saw a high proportion of women who were only screened once within the program, based on their encrypted participant ID number. While some of these women may have repeat screenings within NJCEED across our study years, they may have been assigned a different participant ID due to screening at a different location or other reasons. Another limitation was that we don't know if any of the NJCEED providers or sites targeted screening for high-risk groups (and the variation among providers), which could explain some of the observed differences in county-level testing rates. We also don't know if NJCEED is reaching all of the women who are eligible for the program and if all of these women are seeking cervical cancer screening services through the program, if providers are meeting their catchment area targets for the NJCEED Program, and how much funding they have to meet the needs of the women in their catchment area. Thus, generalizability of these data to women not eligible for NJCEED services is not possible. And finally, lack of data on specific HR-HPV genotypes prevented us 
from examining the type specific prevalence of HR-HPV by subgroup of women, which would really enhance our assessment of cervical cancer risk in this population.

\section{Conclusions}

This is one of the few studies to examine utilization of HR-HPV DNA testing and HR-HPV DNA infection among a sample of medically underserved women who are at high-risk for cervical cancer. These study findings provide insight to individual, area-level factors associated with testing and positive testing results as well as geographic variation across the state in HR-HPV DNA testing, which can inform further exploration of barriers to low utilization of HR-HPV DNA testing, particularly among high risk populations and to develop strategies to increase the utilization rates of this important cervical cancer screening test.

\section{Abbreviations}

API: Asian/Pacific Islander; CaST: Cancer Screening and Tracking System; CDC: Centers for Disease Control and Prevention; DNA: Deoxyribonucleic acid; FDA: Food and Drug Administration; FPL: Federal poverty level; HRHPV: High-risk human papillomavirus; MDE: Minimum Data Element; NBCCEDP: National Breast and Cervical Cancer Early Detection Program; NCl: National Cancer Institute; NHB: Non-Hispanic Black; NHW: Non-Hispanic White; NJBCCCI: New Jersey Breast and Cervical Cancer Control Initiative; NJCEED: New Jersey Cancer Early Education and Detection; NJDOH: New Jersey Department of Health; NJSCR: New Jersey State Cancer Registry; SEER: Surveillance, Epidemiology, and End Results Program; US: United States; ZCTA: Zip code tabulation area

\section{Acknowledgements}

We sincerely thank Candido A. Africa III from the NJCEED Program for his contributions to this work and Sumathy Vasanthan from the NJSCR for conducting the data linkage. We appreciate the $\mathrm{NCl}$ Surveillance,

Epidemiology, and End Results Program and the National Program of Cancer Registries, Centers for Disease Control and Prevention and Rutgers Cancer Institute of New Jersey for its support of the NJSCR and the National Breast and Cervical Cancer Early Detection Program for its support of the NJCEED Program.

\section{Funding}

This research was supported by the National Cancer Institute (Cancer Center Support Grant Number P30 CA072720) through pilot funding awarded A.A.M. Llanos and J. Tsui. Cancer Epidemiology Services, including the New Jersey State Cancer Registry, receives financial support from the following: Surveillance, Epidemiology, and End Results Program of the National Cancer Institute, National Institutes of Health, under contract HHSN $261201300021 \mid$ and control No. N01-PC-2013-00021; National Program of Cancer Registries, Centers for Disease Control and Prevention, under cooperative agreement 5 U58/DP003931; the State of New Jersey; and Rutgers Cancer Institute of New Jersey. The funding sources were not involved in the study design, data collection, data analysis and interpretation, preparation of the manuscript or decision to publish.

\section{Availability of data and materials}

The datasets used and analyzed in this study are available from the New Jersey Cancer Early Education and Detection Program (https://www.nj.gov/ health/ces/public/resources/njceed.shtml) and the New Jersey State Cancer Registry (https://nj.gov/health/ces/cancer-researchers/surv-research/) upon reasonable request.

\section{Authors' contributions}

AAML and JT conceived and supervised the study. AAML assisted with data analysis and interpretation of findings, and led the writing. JT assisted with data analysis, interpretation of findings and critical review of the final manuscript. DR completed the analysis and assisted with interpretation of findings and reviewed the final manuscript. LT provided administrative and technical support and assisted with interpretation of findings and reviewed the final manuscript. AMS assisted with database construction and analysis, interpretation of findings, and critical review of the final manuscript. All authors read and approved the final manuscript.

\section{Ethics approval and consent to participate}

Ethics approval for this study were received by the New Jersey Department of Health, Rutgers Biomedical Health Sciences Institutional Review Board (IRB \#Pro20150001869), and the Scientific Review Board of Rutgers Cancer Institute of New Jersey (CINJ \#131505). A waiver of consent was issued for this study given that the data used were de-identified and obtaining informed consent from nearly 170,000 women enrolled in the NJCEED Program would not have been feasible; and, more importantly, obtaining written consent could have biased what would otherwise be a populationbased sample and jeopardize the reliability of statistical estimates.

\section{Consent for publication \\ Not applicable.}

\section{Competing interests}

The authors declare that they have no competing interests. The content of this work is solely the responsibility of the authors and does not necessarily represent the views of the funding agencies.

\section{Publisher's Note}

Springer Nature remains neutral with regard to jurisdictional claims in published maps and institutional affiliations.

\section{Author details}

${ }^{1}$ Department of Epidemiology, Rutgers School of Public Health, 683 Hoes Lane West, Room 211, Piscataway, NJ 08854, USA. ²Division of Population Science, Rutgers Cancer Institute of New Jersey, New Brunswick, NJ, USA. ${ }^{3}$ Department of Social and Behavioral Health Sciences, Rutgers School of Public Health, Piscataway, NJ, USA. ${ }^{4}$ New Jersey State Cancer Registry, New Jersey Department of Health, Trenton, NJ, USA.

Received: 3 May 2018 Accepted: 26 September 2018

Published online: 03 October 2018

\section{References}

1. Human Papillomavirus (HPV) [http://www.cdc.gov/hpv/parents/vaccine. html].

2. Bouvard V, Baan R, Straif K, Grosse Y, Secretan B, El Ghissassi F, BenbrahimTallaa L, Guha N, Freeman C, Galichet L, et al. A review of human carcinogens_-part B: biological agents. Lancet Oncology. 2009;10(4):321-2.

3. Centers for Disease Control and Prevention. Epidemiology and Prevention of Vaccine-Preventable Diseases. 15th ed. Washington D.C.: Public Health Foundation; 2015

4. Nucleic Acid Based Tests [http://www.fda.gov/medicaldevices/ productsandmedicalprocedures/invitrodiagnostics/ucm330711.htm].

5. Moyer VA. Force USPST: screening for cervical cancer: U.S. preventive services task force recommendation statement. Ann Intern Med. 2012; 156(12):880-91 W312.

6. Committee on Practice B-G. ACOG Practice Bulletin Number 131: Screening for cervical cancer. Obstet Gynecol. 2012;120(5):1222-38.

7. Saslow D, Solomon D, Lawson HW, Killackey M, Kulasingam SL, Cain J, Garcia FA, Moriarty AT, Waxman AG, Wilbur DC, et al. American Cancer Society, American Society for Colposcopy and Cervical Pathology, and American Society for Clinical Pathology screening guidelines for the prevention and early detection of cervical cancer. Am J Clin Pathol. 2012; 137(4):516-42.

8. FDA Approves HPV Test as First Line Screening for Cervical Cancer. [https:// www.cancer.org/latest-news/fdaapproves-hpv-test-as-first-line-screening-forcervical-cancer.html].

9. Price RA. Association between physician specialty and uptake of new medical technologies: HPV tests in Florida Medicaid. J Gen Intern Med. 2010;25(11):1178-85. 
10. Phelan DF, Boitnott JK, Clark DP, Dubay LC, Gravitt PE. Trends of human papillomavirus testing in cervical cancer screening at a large academic cytology laboratory. Obstet Gynecol. 2011;118(2 Pt 1):289-95.

11. Cuzick J, Myers O, Hunt WC, Saslow D, Castle PE, Kinney W, Waxman A, Robertson M, Wheeler CM. New Mexico HPVPRSC: Human papillomavirus testing 2007-2012: co-testing and triage utilization and impact on subsequent clinical management. Int J Cancer. 2015;136(12): 2854-63.

12. Weinmann S, Williams AE, Kamineni A, Buist DS, Masterson EE, Stout NK, Stark A, Ross TR, Owens CL, Field TS, et al. Cervical cancer screening and follow-up in 4 geographically diverse US health care systems, 1998 through 2007. Cancer. 2015;121(17):2976-83.

13. Silver MI, Rositch AF, Phelan-Emrick DF, Gravitt PE. Uptake of HPV testing and extended cervical cancer screening intervals following cytology alone and pap/HPV cotesting in women aged 30-65 years. Cancer Causes Control. 2018;29(1):43-50

14. Watson M, Benard V, Flagg EW. Assessment of trends in cervical cancer screening rates using healthcare claims data: United States, 2003-2014. Prev Med Rep. 2018:9:124-30.

15. Saraiya M, Irwin KL, Carlin L, Chen X, Jain N, Benard V, Montano DE. Cervical cancer screening and management practices among providers in the National Breast and cervical Cancer early detection program (NBCCEDP). Cancer. 2007;110(5):1024-32.

16. Roland KB, Benard VB, Greek A, Hawkins NA, Manninen D, Saraiya M. Primary care provider practices and beliefs related to cervical cancer screening with the HPV test in federally qualified health centers. Prev Med. 2013;57(5):419-25.

17. Hoover K, Koumans EH, Montano D, Kasprzyk D, Freeman C, Greek A, Jain N, Irwin K. Access of black, Hispanic, and nonprivately insured women to liquid-based cytology, human papillomavirus DNA testing, and on-site colposcopy in the United States. J Low Genit Tract Dis. 2009;13(1):17-27.

18. de la Cruz MS, Young AP, Ruffin MT. Human papillomavirus (HPV) testing for normal cervical cytology in low-risk women aged 30-65 years by family physicians. J Am Board Fam Med. 2013;26(6):720-7.

19. Benard VB, Johnson CJ, Thompson TD, Roland KB, Lai SM, Cokkinides V, Tangka F, Hawkins NA, Lawson H, Weir HK. Examining the association between socioeconomic status and potential human papillomavirusassociated cancers. Cancer. 2008;113(10 Suppl):2910-8.

20. Centers for Disease C. Prevention: Cancer screening - United States, 2010. MMWR Morb Mortal wkly Rep. 2012;61(3):41-5.

21. Fedewa SA, Cokkinides V, Virgo KS, Bandi P, Saslow D, Ward EM. Association of insurance status and age with cervical cancer stage at diagnosis: National Cancer Database, 2000-2007. Am J Public Health. 2012;102(9):1782-90.

22. Mobley LR, Kuo TM, Driscoll D, Clayton L, Anselin L. Heterogeneity in mammography use across the nation: separating evidence of disparities from the disproportionate effects of geography. Int J Health Geogr. 2008;7:32.

23. Schnake-Mahl AS, Sommers BD. Health care in the suburbs: an analysis of suburban poverty and health care access. Health Aff (Millwood). 2017:36(10):1777-85.

24. Silver D, Blustein J, Weitzman BC. Transportation to clinic: findings from a pilot clinic-based survey of low-income suburbanites. J Immigr Minor Health. 2012;14(2):350-5.

25. Tsui J, Gee GC, Rodriguez HP, Kominski GF, Glenn BA, Singhal R, Bastani R. Exploring the role of neighborhood socio-demographic factors on HPV vaccine initiation among low-income, ethnic minority girls. J Immigr Minor Health. 2013;15(4):732-40.

26. Henry KA, Stroup AM, Warner EL, Kepka D. Geographic factors and human papillomavirus (HPV) vaccination initiation among adolescent girls in the United States. Cancer Epidemiol, Biomarkers Prev. 2016;25(2):309-17.

27. Chen JY, Diamant AL, Kagawa-Singer M, Pourat N, Wold C. Disaggregating data on Asian and Pacific islander women to assess cancer screening. Am J Prev Med. 2004;27(2):139-45.

28. Echeverria SE, Carrasquillo O. The roles of citizenship status, acculturation, and health insurance in breast and cervical cancer screening among immigrant women. Med Care. 2006;44(8):788-92.

29. Swan J, Breen N, Coates RJ, Rimer BK, Lee NC. Progress in cancer screening practices in the United States: results from the 2000 National Health Interview Survey. Cancer. 2003;97(6):1528-40.

30. Tsui J, Saraiya M, Thompson T, Dey A, Richardson L. Cervical cancer screening among foreign-born women by birthplace and duration in the United States. J Women's Health (Larchmt). 2007;16(10):1447-57.
31. Shelton RC, Jandorf $L$, King $S$, Thelemaque $L$, Erwin DO. Cervical cancer screening among immigrant Hispanics: an analysis by country of origin. J Immigr Minor Health. 2012;14(4):715-20.

32. Colby SL, Ortman JM. Projections of the Size and Composition of the US Population: 2014 to 2060, Current Population Reports, P25-1143. Washington, DC: US Census Bureau; 2014.

33. Arbyn M, Castellsague X, de Sanjose S, Bruni L, Saraiya M, Bray F, Ferlay J. Worldwide burden of cervical cancer in 2008. Ann Oncol. 2011;22(12):2675-86.

34. Torre LA, Bray F, Siegel RL, Ferlay J, Lortet-Tieulent J, Jemal A. Global cancer statistics, 2012. CA Cancer J Clin. 2015;65(2):87-108.

35. Kahn JA, Lan D, Kahn RS. Sociodemographic factors associated with highrisk human papillomavirus infection. Obstet Gynecol. 2007;110(1):87-95.

36. Watson M, Saraiya M, Benard V, Coughlin SS, Flowers L, Cokkinides V, Schwenn M, Huang Y, Giuliano A. Burden of cervical cancer in the United States, 1998-2003. Cancer. 2008;113(10 Suppl):2855-64

37. Saraiya M, Ahmed F, Krishnan S, Richards TB, Unger ER, Lawson HW. Cervical cancer incidence in a prevaccine era in the United States, 1998-2002. Obstet Gynecol. 2007;109(2 Pt 1):360-70.

38. American Cancer Society. Cancer Facts \& Figures 2016. Atlanta: American Cancer Society; 2016.

39. Cooper CP, Saraiya M. Primary HPV testing recommendations of US providers, 2015. Prev Med. 2017:105:372-7.

40. Lee JW, Berkowitz Z, Saraiya M. Low-risk human papillomavirus testing and other nonrecommended human papillomavirus testing practices among $U$. S. health care providers. Obstet Gynecol. 2011;118(1):4-13.

41. Roland KB, Soman A, Benard VB, Saraiya M. Human papillomavirus and Papanicolaou tests screening interval recommendations in the United States. Am J Obstet Gynecol. 2011;205(5):447 e441-8.

42. Yabroff KR, Saraiya M, Meissner HI, Haggstrom DA, Wideroff L, Yuan G, Berkowitz Z, Davis WW, Benard VB, Coughlin SS. Specialty differences in primary care physician reports of papanicolaou test screening practices: a national survey, 2006 to 2007. Ann Intern Med. 2009;151(9):602-11.

Ready to submit your research? Choose BMC and benefit from:

- fast, convenient online submission

- thorough peer review by experienced researchers in your field

- rapid publication on acceptance

- support for research data, including large and complex data types

- gold Open Access which fosters wider collaboration and increased citations

- maximum visibility for your research: over $100 \mathrm{M}$ website views per year

At $\mathrm{BMC}$, research is always in progress.

Learn more biomedcentral.com/submissions 